\title{
スマートアクチュエータ材料成膜と微細加工の MEMS への応用
}

\author{
峯田貴 ${ }^{a}$ \\ ${ }^{\mathrm{a}}$ 山形大学大学院理工学研究科 ( $7992-8510$ 山形県米沢市城南 4-3-16)
}

Film Deposition and Micro-machining of Smart Actuator Materials for MEMS Applications

Takashi MINETA ${ }^{\text {a }}$

${ }^{a}$ Graduate School of Science and Engineering, Yamagata University(4-3-16 Jounan, Yonezawa-shi, Yamagata 992-8510)

Keywords : Shape Memory Alloy, Magneto-Strictive Alloy, Film Deposition, Micro-Machining, MEMS

\section{1.はじめに}

本格的な MEMS (Micro Electro Mechanical Systems)技術が 登場してから 30 年近くが経ち, 加速度, 角速度 (ジャイロ), 磁気，熱などの各種マイクロセンサや，インクジェットヘッ ド, DLP プロジェクタ素子などの各種マイクロアクチュエー タとして, 幅広い応用分野において実用化され, 身近な生活 にも浸透してきている ${ }^{1)}$ 。MEMS 形成技術は半導体形成プロ セスの応用からスタートし, Si 基板自体を立体貫通加工す るバルクマイクロマシニングと, Si 化合物等の薄膜を積層 形成して下部の犠牲層を除去する表面マイクロマシニングを 中心に進歩してきた ${ }^{2)}$ 。さらに高い機能大きなメカニカルな 動作などを発揮するためには, 機能性材料の付加が必要であ り，Si テクノロジーを基盤とした MEMS へ，様々な材料の 薄膜形成と微細加工技術を融合されてきており, 今後もその 傾向は続いていく。センサ薄膜, アクチュエー夕薄膜, バイ オケミカル薄膜等々, それぞれの分野における詳細な専門書 や解説論文が出版されており，詳細はそちらを参照されたい ${ }^{3)}$ 本稿では, マイクロアクチュエータへの応用を指向した機 能性材料である形状記憶合金と磁歪合金にフォーカスし, MEMS デバイスへの応用について薄膜形成と微細加工プロ セスの観点から紹介する。

\section{2. 形状記憶合金厚膜形成と MEMS デバイスへの応用}

\section{1 SMA 厚膜形成}

形状記憶合金 (Shape memory alloy：SMA)の原理やマイク ロアクチュエータへの応用についても, 専門書が出版されて おり, 詳細はそちらを参照されたい ${ }^{3), 4)}$ 。SMA アクチュエー 夕が発揮できる単位体積あたりのエネルギー密度 (発生力 $\times$ 変位 /体積) は $10^{7} \mathrm{~J} / \mathrm{m}^{3}$ オーダーに達し, 熱型, 静電型, 圧 電型などの種々のマイクロアクチュエータ技術と比べて桁違 いに大きい ${ }^{5)}$ 。多くの合金で形状記憶特性が見出され，生体 適合性のある $\mathrm{NbTi}$ 系合金なども開発されているが ${ }^{6}$, 大き なエネルギー密度を活かして工業的に実用化されているのは， ほとんどが TiNi 系合金である。
1990 年頃からスパッタ法を中心とした SMA の薄膜形成の

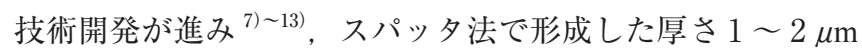
の TiNi 形状記憶合金薄膜では, 形状回復応力と回復歪とも 実用的なバルク材料のレベルに達している ${ }^{12)}$ 。TiNi 系 SMA では， $1 \%$ 以下の僅かな組成の違いでも変態温度が大きく影 響されるため, 精密な組成制御が重要である。合金ターゲッ トを用いたスパッ夕成膜では, Ti と Ni のスパッ夕速度差に よりターゲットとは異なる組成の膜が形成され ${ }^{8)}$, 長期の使 用中にターゲット表面の組成も変動していく。安定した組成 を得るためには，Ti， Ni 等の構成元素毎に分割したターゲッ 卜を用いる成膜法が有効である ${ }^{5), 13)}$ 。スパッ夕成膜では, 高 エネルギーの粒子が飛来して堆積して非晶質の膜になりやす く，成膜後に結晶化のための高温熱処理を要する場合が多い。 筆者らは数十 $\mu \mathrm{m}$ クラスの厚膜形成を目指し, 図 1 に示す 成膜装置を用いた特殊なフラッシュ蒸着法による SMA 成膜

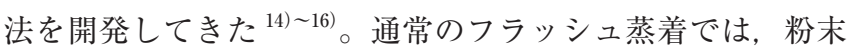
状の蒸着源が用いられるが, SMA 粉末は入手が容易ではな

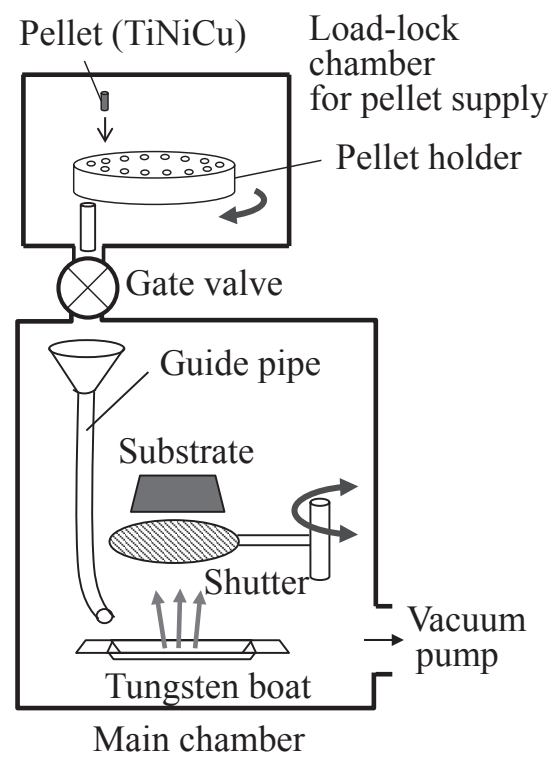

図 1 SMA 厚膜形成用フラッシュ真空蒸着の概要 
いため, TiNi 系合金ワイヤを数 $\mathrm{mm}$ 長のペレット状にして 蒸着源として用いている。装置の上部の回転式ホルダーから ペレットを 1 個ずつ蒸着チャンバー内の加熱ボートに投下し て蒸発を開始するが，例えば TiNiCu 3 元合金ペレットを用 いた場合では, 蒸気圧の違いに応じて $\mathrm{Cu}, \mathrm{Ni}$, および Ti が 時間差を伴って蒸発し, 特に蒸発開始直後には大きく蒸気の 組成が変動する。膜厚方向での組成の変動を防いで所望の膜 組成を得るために, 蒸発し始めてから所定の時間経過後に蒸 着用シャッターを開いて基板への成膜を開始し, 所定の成膜 時間後にシャッターを閉じて成膜を停止して, 蒸着した SMA 薄膜の組成を制御している。1ペレットあたり成膜さ れるのは $200 \mathrm{~nm}$ 程度の膜厚であるが, 多数のペレットを投 下して繰り返し積層成膜して厚膜化していく。 $\mathrm{Cu}$ を 7 at.\% 添加した合金ペレットを用いても，膜中に取り込まれる $\mathrm{Cu}$ は 0.5 at.\% 程度になり, TiNi 2 元系合金に近い形状記憶特性 となるが, 微量の $\mathrm{Cu}$ 添加効果によって積層成膜過程での粒 成長が抑制されるため, $30 \mu \mathrm{m}$ を超える厚膜を形成しても, 薄い膜厚の場合と同様に緻密な結晶組織をもち, 柔軟で良好 な厚膜を得ることができる ${ }^{15)}$

\section{2 SMAの微細エッチング}

TiNi 系 SMA は, 化学的に非常に安定な難エッチング材料 であるが, フッ化水素酸と硝酸の混酸でエッチングが可能で ある。筆者らが 3 元系の Ti- $44 \mathrm{at} \% \mathrm{Ni}-6 \mathrm{at} \% \mathrm{Cu}$ を用いて行った 研究例では, $\mathrm{HNO}_{3}$ 濃度が低いと $\mathrm{Cu}$ リッチの析出物が生成 してエッチングを阻害するが, $\mathrm{HF}$ に対して $\mathrm{HNO}_{3}$ の比率を 高くすることで良好にエッチング可能である ${ }^{17)}$ 。また, $\mathrm{SiCl}_{4}$ を用いた反応性イオンエッチング (RIE) の研究例もある が ${ }^{11)}, 10 \mathrm{~nm} / \mathrm{min}$ 程度のきわめて遅いエッチング速度である。 また，ポリインド膜パターンを用いて SMA スパッタ薄膜の リフトオフパターニングも可能である ${ }^{11}$ 。

筆者らは, 電解エッチングによる微細パターニング手法を 開発し，実用レベルの技術として確立してきた。フォトレジ ストマスクパターンを形成し, ステンレス鋼板の陰極と対向 させて電解液中で両極間に電圧を印加する手法である ${ }^{18)}$ 。 水溶液系の電解液を用いた場合は, 溶解に加えて陽極酸化に よる被膜形成も同時に生じて極端に荒れた加工面になりやす いが，様々な種類の電解液を検討し， $\mathrm{LiCl}$ を溶質に用いた

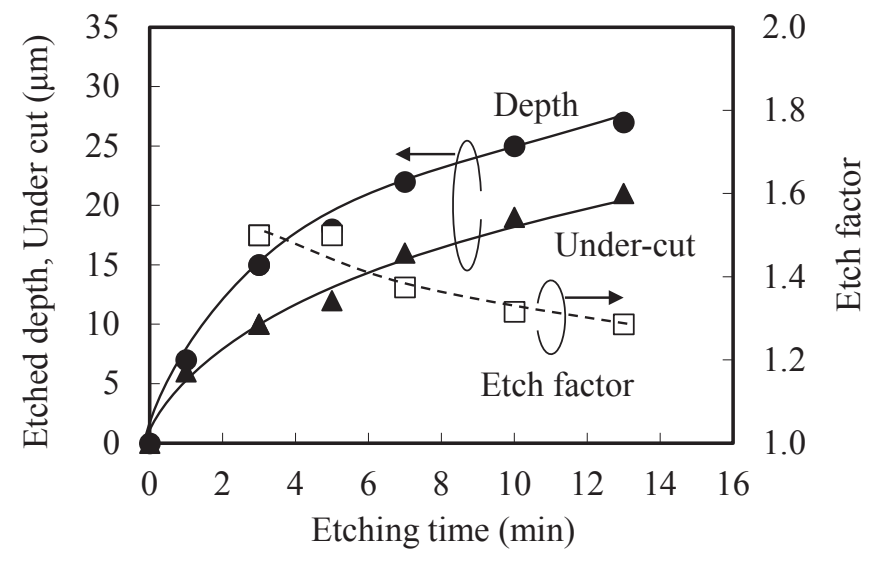

図 2 TiNi 合金の電解エッチング特性

$(1 \mathrm{M} \mathrm{LiCl} /$ エタノール電解液, 印加電圧 $8 \mathrm{~V})$
メタノールやエタノール溶媒を用い, 良好なエッチングが可 能であることを見出した ${ }^{19), 20) 。 ~}$

図 2 は, 定電圧印加による電解エッチングによって TiNi 合金を微細溝加工した際におけるエッチング深さ, アンダー カット幅, およびエッチファクタ(エッチング深さ/アンダー カット幅)の推移である ${ }^{21)}$ 。エッチファクタ $1.5 \sim 2.0$ の深 いエッチングが可能であり, 電解研磨効果により鏡面に近い 平滑なエッチング面が得られる利点があるが，エッチングの 進行に伴って加工面の形状と表面積が変化し, また, 加工溝 内への溶出物の滞留の影響によりエッチング深さは頭打ちに なっていき, エッチファクタも変動していく。また, 開口幅 が広いと面荒れが生じやすく，また，パターンエッジ部に電 解電流が集中して W 字型の加工断面形状になりやすいなど の特徵があり ${ }^{21)}$, 精密なエッチング形状を得るためには, これらの特性をあらかじめ実験的に把握しておく必要がある。 $\mathrm{TiNiCu}$ 合金の場合でも $\mathrm{Cu}$ の影響は極めて小さく, 上記の TiNi とほほ同様の特性で電解エッチングできる ${ }^{17)}$ 。また, 貫通加工の際には電解電流のバランスが維持できずに不均一 になりやすいため, 導電性の $\mathrm{Cu}$ や $\mathrm{Ni}$ 等の下地層を設けて おき，下地層の途中まで貫通加工した後で下地層を選択的に 除去するような工夫が必要である ${ }^{21), 22)}$

図 3 は外径 $1 \mathrm{~mm}$ の $\mathrm{TiNiCu}$ 合金チューブからエッチングに より形成した能動カテーテル用屈曲アクチュエータである ${ }^{17)}$ 円筒リソグラフィ法によって SMA チューブの側面にレジス トパターンを形成し, 円筒状の対向電極を用いた電解エッチ ングによって超微細ばね型アクチュエータ形状に加工した後 に(ハーフエッチング), チューブ内面からフッ化水素酸／硝 酸でエッチングして貫通加工したものである(肉厚 30 $40 \mu \mathrm{m})$ 。また, SMA チューブ内面に無電解めっきで $\mathrm{Cu}$ 導 電層を設けてから電解エッチングで貫通加工して同様の SMA チューブ型アクチュエータを形成した例もあるが，細 径チューブ内への均一な導電層形成は容易ではない ${ }^{23)} 。 こ$ のように筆者らが開発してきた微細加工プロセスを適用して, 平板状の基板のみならず, 細径の円筒面の微細加工も可能に なってきたが, 超弾性特性の TiNi 系合金チューブに比べ,

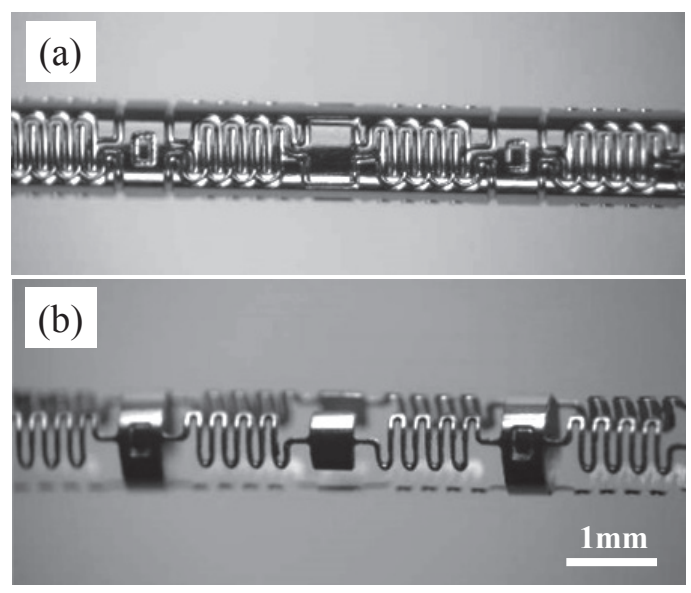

図 3 能動カテーテル用 $\mathrm{TiNiCu}$ 合金チューブ型アクチュエータの 電解エッチングによる微細加工例

(a) 電解エッチングによる円筒面の微細加工

(b)内面化学エッチングによる貫通後 
形状記憶特性をもつ細径の SMA チューブは入手が難しい。 筆者らはSMA チューブの自作をめざし, $\mathrm{Cu}$ のコアパイプ 上へ SMA 厚膜を回転フラッシュ蒸着し, 同様の形状をもつ 能動カテーテル屈曲用アクチュエータ形成も試みたが ${ }^{24)}$, 回転成膜で厚膜化した場合は, 結晶成長の様相が平板上の成 膜とは異なり，所望の形状回復温度や柔軟性をもつ SMA 円 筒素材を得ることが鍵である。

\section{3 SMA 厚膜の MEMS デバイスへの応用}

薄膜形成した SMA を用い，これまでマイクロ流体バルブ, マイクログリッパなど，発生力と変位を要するデバイスへの 応用を目指した研究が数多く実施されてきた ${ }^{4)}$ 。

筆者らは, SMA フラッシュ蒸着厚膜 $(10 \sim 30 \mu \mathrm{m}$ 厚)を用 いて，血管クリップ型拍動センサ ${ }^{25)}$ 27)，生体膜ハンドリン グ用のマイクログリッパなど ${ }^{28)}$ ，把持型マイクロデバイス の開発に取り組んでいる。 $\mathrm{TiNiCu}$ 合金薄膜をフラッシュ蒸 着によって $\mathrm{Cu}$ 基板上に成膜し, 基板ごと平面の状態で形状 記憶処理を行い, 絶縁膜(感光性ポリイミド), Pt 薄膜配線 パターンの形成後に, 電解エッチングによってクリップ形状 等に加工する。 $\mathrm{Cu}$ 基板を溶解して SMA デバイスを独立させ， フレキシブルプリント配線を接合する。

図 4 (a) は作製した拍動センサである。皮膚移植手術など の際に移植して吻合した外径 $1 \mathrm{~mm}$ 程度の微細血管にワン タッチで取り付けて, 拍動を計測して血栓生成による血流阻 害のモニタを目的として開発したデバイスである。血管の把 持と開放動作を 1 回のみ行う使い捨て使用を想定しており, 使用時にピンセット等でアウターアームを「くの字」にたわ ませてクリップを解放状態にしておき，アームの根元部を Pt 薄膜ヒーターの局所加熱によって形状回復させて微細血 管を把持する。インナーアーム部に設けた Pt 薄膜型ひずみ センサにより, 外径 $1 \mathrm{~mm}$ の血管径の拍動による変化を $10 \mu \mathrm{m}$ 以下の分解能で検出できる高感度の拍動センサである。 手術直後の血栓生成の高リスク時期 (2 日程度)の経過後に, アウターアーム部の中間点を加熱して平坦状に形状回復させ て血管を開放し, 皮膚外へ抜き去る構想である。形状回復温 度が約 $60{ }^{\circ} \mathrm{C}$ の SMA 膜を用いており, 大気中での把持およ び開放では $2 \mathrm{~s}$ 程度で動作完了するが，皮膚下を想定して疑 似生体組織内へ埋め込んだ場合には数 $10 \mathrm{~s}$ を要し ${ }^{27)}$ ，その間
の生体組織への熱ダメージの影響が懸念され, 安全性をクリ アして実用化していくためには形状回復温度の抑制が課題で ある。

図 4 (b) は先端部をさらに小型化し, 同様の形成プロセスを 用いて作製した可逆動作型のマイクログリッパ素子である ${ }^{28)}$ フラッシュ蒸着で成膜した $30 \mu \mathrm{m}$ 厚の SMA を用い, 膜の内 部応力による初期たわみと平坦状への形状回復により，加熱 駆動の ON / OFF に応じて繰り返し開閉動作が可能である。 再生医療分野におけるシャーレ内での生体シートをハンドリ ングする応用を目指したデバイスであるが，小型化に伴い熱 伝導による非加熱部の誤動作が大きくなり, 現在, 変形しな い異種材料の箔材と組み合わせたデバイスを開発中である。 また，生体膜への熱ダメージを最小に抑えるためには，やは り形状回復温度を抑制したSMA 厚膜の安定した形成法が必 要となる。

図 5 は SMA フラッシュ蒸着膜で作製した触覚ディスプレ イ用のマイクロアクチュエータアレイである ${ }^{29)}$ 。XY 面内に 配置したマイクロピンアレイをアクチュエータによって上下 動し, 触れている手指等の皮膚へ点字のような文字パターン
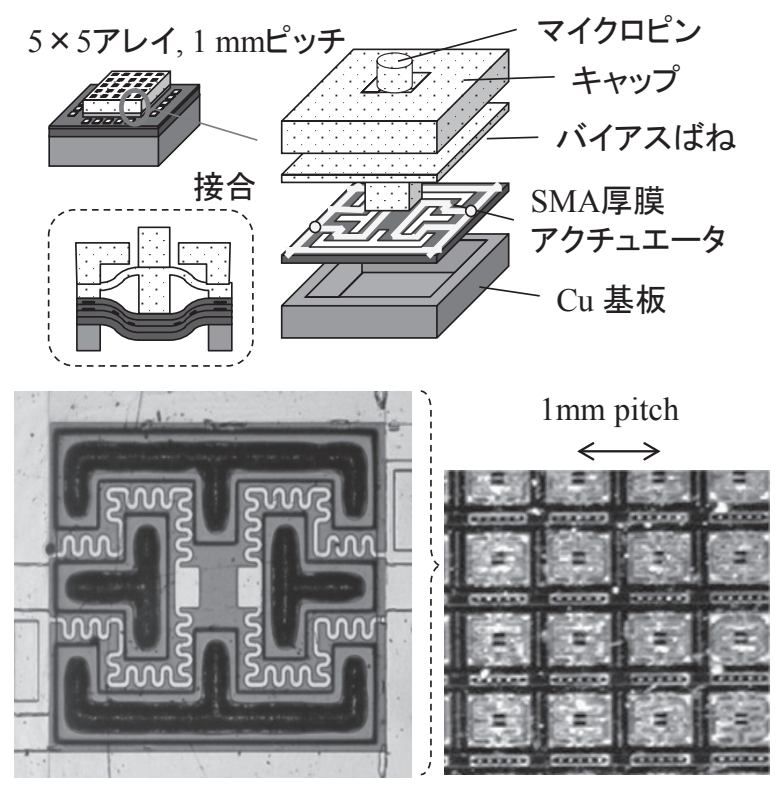

図 5 SMA 厚膜型触覚ディスプレイ素子
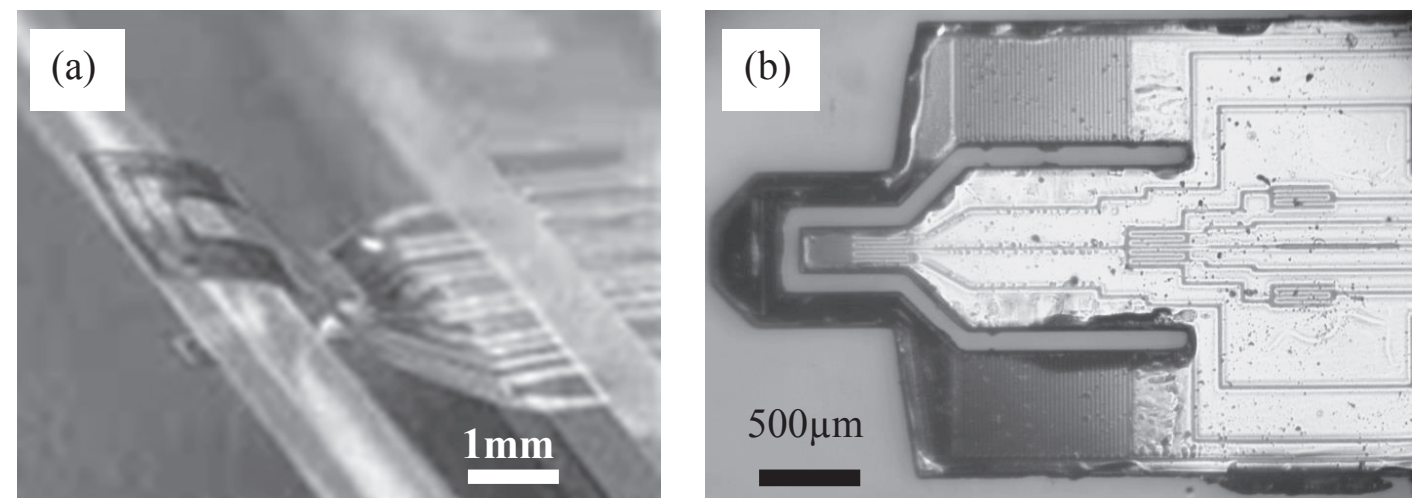

図 4 SMA 厚膜型マイクログリッパデバイス

(a) 血管クリップ型拍動センサ

(b) 可逆駆動型マイクログリッパ 
や触感を感じさせて情報伝達する素子である。圧力駆動型, 圧電アクチュエータ型, SMA コイルアクチュエータ型など の種々の触覚デイスプレイが開発されているが, 皮膚下の触 覚受容器へ十分な刺激を与える変位 (振幅) と発生力を生み出 すためには, 大型のアクチュエータ機構が必要となり, 数 $\mathrm{cm}$ を超える厚さをもつ大型の機器となる。組立式のメカでは狭 ピッチでアレイ状に配列することが難しく，また，作製コス 卜も高いものとなり, 用途が著しく瀬減される。基板上へ成 膜したSMAを用いるプレーナ素子構造の MEMS 型触覚 ディスプレイも，アイデアとしては提案されていたが ${ }^{30)}$, 実際のデバイスを実現するためも SMA 膜形成と微細加工プ ロセスが鍵となっていた。

図 5 に示す触覚ディスプレイ素子は, 前述のグリッパデバ イスと同様の形成プロセスを基盤とし， $5 \times 5$ の SMA アク チュエータを $1 \mathrm{~mm}$ ピッチで配列したプレーナ構造の MEMS 型デバイスである。 $\mathrm{Cu}$ 基板上へ SMA 膜 $(10 \mu \mathrm{m})$ を形成し, 絶縁層と Pt 薄膜ヒーター配線層の形成後に, 電解エッチン グで SMA をジグザグばね型アクチュエータ形状に加工した。 最後に SMA パターン越しに $\mathrm{Cu}$ 基板をエッチングし, サイ ドエッチングを利用して SMA アクチュエータ部の裏側を精 密に中空化している。指先の触二点閾值の最小值である $1 \mathrm{~mm}$ のピッチで ${ }^{31)}$, 精密なアレイ状アクチュエータの形成 が可能になった。

SMA を繰り返し上下動作させるためにはSMA の形状回 復効果による変形と押し合うバイアスばねが必要であり, 筆 者らは, 硬質エポキシ系の厚膜レジスト(化薬ケム, SU8)を 用いて，バイアスばね層，マイクロピン，およびカバー層を リソグラフィにより一括形成する手法を開発し，上記の SMA 厚膜アクチュエータ層と接合して, 厚さ約 $2 \mathrm{~mm}$ の MEMS チップ状デバイス $(5 \times 5$ マイクロピンアレイ, $1 \mathrm{~mm}$ ピッチ)を実現した ${ }^{32)}$ 。高い駆動周波数では SMA アクチュ エータの熱応答が遅いために動作振幅が低下するが，人体の 皮膚下の触覚受容器であるマイスナー小体が高感度をもつと される $15 \sim 30 \mathrm{~Hz}$ の駆動では, 十分に検知可能な振幅と発 生力を実現することができ ${ }^{32}$, 超薄型の触覚ディスプレイ 素子として今後の用途拡大を期待している。

\section{3．磁歪合金薄膜形成と MEMS デバイスへの応用}

磁歪材料は, 磁束印加により磁区の配列が揃うように変化 することにより歪み(磁歪)を発生する。磁束に沿って伸長す る正の磁歪と, 純 Ni のように収縮する負の磁歪の場合がある。 磁束印加による変形をアクチュエータへ応用したり, 逆に外 部から応力を加えて磁区の配列変化によって磁気的特性が変 わる逆磁歪効果を用い, 振動を磁束発生に変換する振動セン サや振動発電デバイス等にも用いられている ${ }^{33)}$ 。また, 磁 歪合金で圧電材料(チタン酸ジルコン鉛：PZT 等)をサンド イッチ構造にし, 磁歪による伸びを圧電材料の起電力として 出力する Magneto-electric (ME) センサが開発され ${ }^{34) ~ 36), ~ M E M S ~}$ 構造の Si 感知レバーへ PZT 圧電薄膜と磁歪薄膜を積層し, 高 感度磁気センサを目指した取り組みも行われている ${ }^{37), 38)}$ 。

大きな磁歪を発現する材料として $\mathrm{Tb}_{0.3} \mathrm{Dy}_{0.7} \mathrm{Fe}_{2.0}$ (Terfenol-D) ${ }^{36)}$, $\mathrm{Fe}_{80} \mathrm{Ga}_{20}{ }^{33)}, \mathrm{FeCo}^{39)}, \mathrm{FePd}^{34) \sim 35), 38)}$ などの多くの種類が知ら
れており, スパッタ成膜を中心にした薄膜形成と各種磁気デ バイスへの応用も進んでいる。最適組成の探索のために, 組 成が面内分布を生じるように基板上へ磁歪膜を形成して膜の 特性を一括計測するコンビナトリアル法も試みられており, 基板内にアレイ状に複数配列した MEMS カンチレバー等も 評価手法として用いられる ${ }^{41)}$

筆者らは, FePd 合金薄膜を用いたデバイス開発を試みて いる。バルク材料では, 磁束によって双晶構造が歪む磁性形 状記憶特性により数 $1000 \mathrm{ppm}$ の変形も可能であり, また, シンプルな磁歪発現のみでも数 $10 \mathrm{ppm}$ オーダーの歪みの発 生が可能である。図 6 に示すように, フォトレジストパター ン上へスパッタ成膜し, リフトオフにより良好な微細パター ニングが可能である ${ }^{42)}$ 。また, 塩化第二鉄溶液で比較的容 易にエッチングも可能であるが，レジストマスクとの親和性 に配慮しないと大きなサイドエッチングが生じやすい ${ }^{42)}$ 。

バルク材料では $\mathrm{Fe}_{70} \mathrm{Pd}_{30}$ の組成において最も高い磁歪を発 現することが知られているが, 薄膜の場合には結晶配向性や 膜応力の状態の影響も受け, 必ずしも適正条件は一定ではな い。筆者らの研究例では, 無加熱スパッタ成膜した場合には, $\mathrm{Fe}_{60} \mathrm{Pd}_{40}$ 膜で $60 \mathrm{ppm}$ (0.25 Te 印加)の大きな磁歪が得られ, 膜厚 1 〜 $2 \mu \mathrm{m}$ のときが最も大きい磁歪であった ${ }^{43)}$ 。また, 成膜後に $400{ }^{\circ} \mathrm{C}, 30 \mathrm{~min}$ 程度のアニール処理することで, 磁 歪をさらに約 3 倍増大できることも見出している ${ }^{44)}$

図 7 は, $\mathrm{Fe}_{60} \mathrm{Pd}_{40}(2 \mu \mathrm{m}) / \mathrm{PZT}(0.7 \mu \mathrm{m}) / \mathrm{Si}(10 \mu \mathrm{m})$ を積層 した MEMS カンチレバー型の ME センサのプロトタイプで ある ${ }^{38)}$ 。PZT 膜の上下面には $\mathrm{Pt} / \mathrm{Ti}$ 電極膜パターンも形成し てある。カンチレバーを共振駆動し, 磁歪によって生じる共 振変化により磁場をセンシングする。また，共振振動子を両 端支持型のブリッジ構造とし, 磁歪膜を積層した別のブリッ ジにより共振ブリッジを大きく変形させる試みもなされてい る ${ }^{38)}$ 。Si 上へ薄膜積層した MEMS デバイス構造であり, 熱 歪みの影響による温度ドリフトが極めて大きいという久点は あるが, 地磁気レベルの磁気センシングは可能であり, 磁歪 特性の向上とデバイス構造の最適化を図ることにより,さら に感度向上の余地がある。

磁歪膜を用いたアクチュエー夕は，通電を必要とせずに， 外部からの磁場印加で変形できるため, 絶縁対策やリード線 を引き回すことなく液中での使用が容易であることも大きな 利点である。マイクロ流路内に磁歪膜 / $\mathrm{Si}$ 積層型の原子間

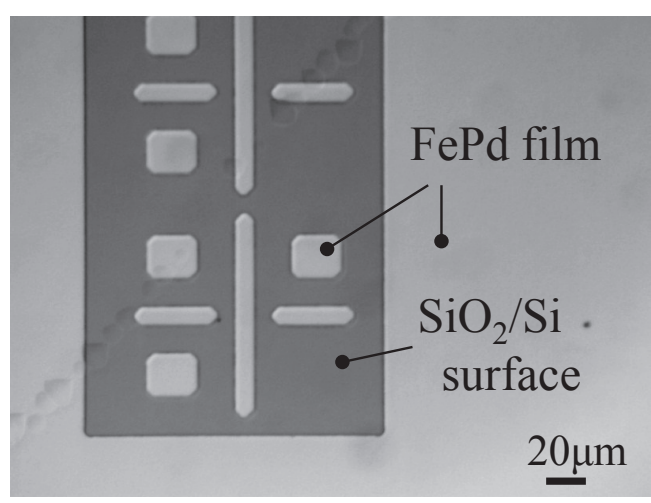

図 $6 \mathrm{Fe}_{70} \mathrm{Pd}_{30}$ 磁歪合金スパッタ膜のリフトオフによるパターニング 

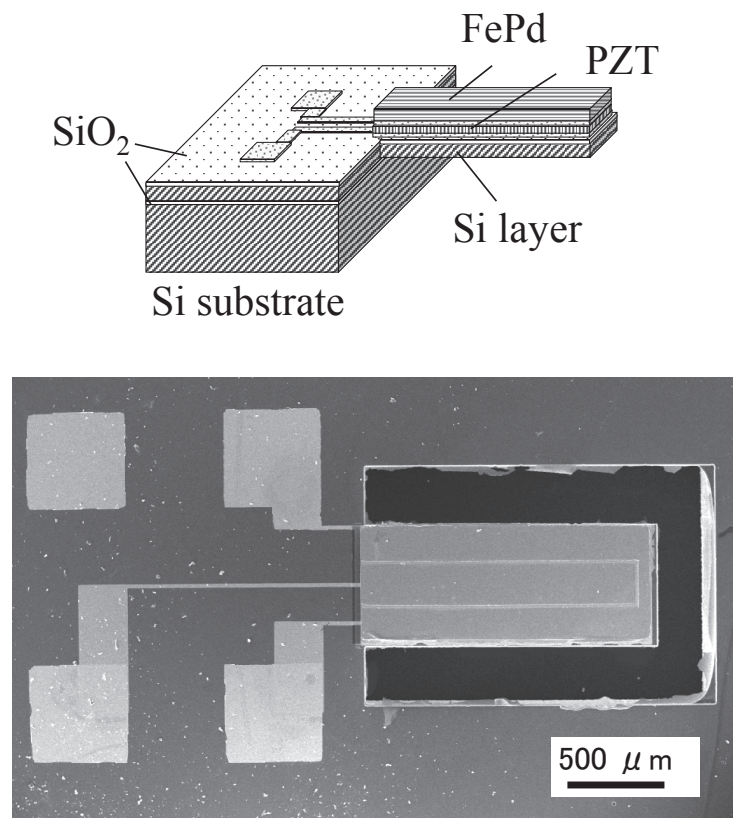

図 7 磁歪膜／圧電膜を積層した MEMS カンチレバー型 ME センサ

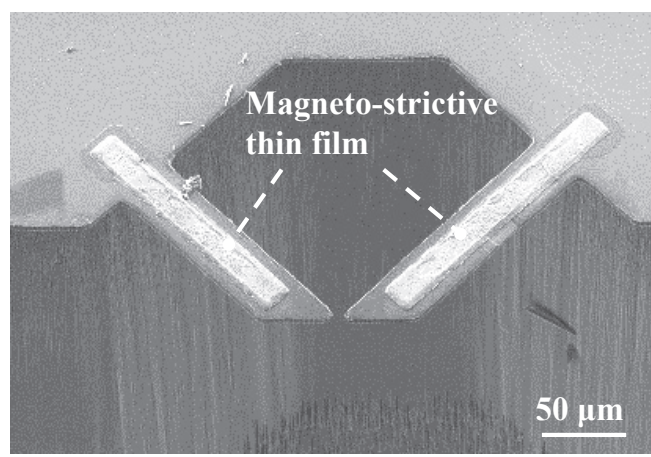

図 8 磁歪膜により切替操作するデュアル AFM カンチレバー

力顕微 (AFM) カンチレバーを作り込んで, 外部から交流磁場 を印加して液中で共振させるデバイスなどの応用例がある ${ }^{45)}$ 筆者らは図 8 に示すように, 磁歪膜を積層したデュアル

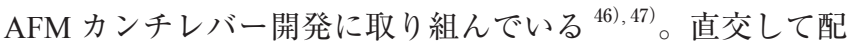
置した各カンチレバー先端にはサブ $\mu \mathrm{m}$ ギャップで近接させ たナノ探針を Si 自己整合エッチングによって形成しており， 印加する磁場の方向を変えて, たわませるカンチレバーを切 り替えて, 各カンチレバーの異なる機能を使い分けるデバイ スである。一方のカンチレバーを磁場印加によってたわませ て試料表面から離し, 磁場と直交する方のカンチレバーを AFM プローブとして用いる構造にすることで, 印加磁場の 変動の影響をほぼ受けない安定した操作が可能になる ${ }^{47) 。 ~}$ デュアル AFM カンチレバーを用いることにより，例えば, 片方でナノスクラッチ等の表面操作を行い, 他方でその場で の高解像観察などが可能になる。筆者らは近年, 片方のカン チレバーを中空構造にして液体をデリバリする機能を付加す るデバイス開発にも取り組んでいる ${ }^{48)} 。$

\section{4.おわりに}

異なる機能をオンチップで集積化して高機能化, 多機能化
していくのがMEMS 技術の大きな特徴である。紙面の都合 で本稿では形状記憶合金および磁歪合金のみ取り上げたが, 多種多様の薄膜形成, 表面処理, 超微細パターニングを基盤 としたMEMSへの応用が進んでおり, 今後もさらに幅広く 様々なスマート材料の MEMS への融合が進められると期待 しており，筆者らも多様化した実用デバイスへつながってい く技術開発に貢献していきたいと考えている。

(Received May 15, 2017)

\section{文献}

1 ) 江刺正喜; 電気学会論文誌E, 134, 1 (2014).

2 ) 江刺正喜;はじめてのMEMS (森北出版, 2011)

3 ) 例えば, R. Ghodssi, P. Lin (eds.); MEMS materials and Process Handbook (Springer, 2011).

4 ) M. Kohl ; Shape Memory Microactuator (Springer, 2004).

5 ) P. Krulevitch, A. P. Lee, P. B. Ramsey, J. C. Trevino, J. Hamilton, M. A. Northrup ; J. Microelectromechanical Systems, 5, 270 (1996).

$6)$ E. Takahashi, T. Sakurai, S. Watanabe, N. Masahashi, S. Hanada ; Materials Transactions, 43, 2978 (2002).

7 ) J. A. Walker, K. J. Gabriel ; Sensors and Actuators, A21-A23, 243 (1990).

8 ) J. D. Busch, A. D. Johnson ; J. Appl. Phys., 68, 6224 (1990).

9 ) A. Ishida, M. Miyazaki ; Thin Films, 228, 210 (1993).

10) S. Miyazaki, A. Ishida ; Materials Sci. and Eng. A, 273 (1999).

11) 中村滋男, 中村洋介, 安宅学, 藤田博之; 電気学会論文誌 $\mathrm{E}, 118-\mathrm{E}$, 27 (1997).

12）宮崎修一; 応用物理, 69, 38 (2000).

13）石田 章, 澤口孝宏, 佐藤守夫; 金属, 74,33 (2004).

14) E. Makino, M. Uenoyama, T. Shibata ; Sensors and Actuators A, 71, 187 (1998).

15) T. Mineta, K. Kasai, Y. Sasaki, E. Makino, T. Kawashima, T. Shibata ; Microelectronic Eng., 86, 1274 (2009).

16）鎌田隆宏, 峯田 貴; 第5回マイクロナノ工学シンポジウム, 71 (2013).

17) T. Mineta, T. Deguchi, E. Makino, T. Kawashima, T. Shibata ; Sensors and Actuators A, 165, 392 (2011).

18）牧野英司, 柴田隆行, D. M. Allen; 表面技術, 49, 887 (1998).

19）峯田 貴; 表面技術, 54, 145 (2003).

20) T. Mineta ; J. Micromech. and Microeng., 14, 76 (2004).

21) T. Mineta, E. Makino ; J. Micromech. Microeng., 20, 125012 (2010).

22) T. Mineta, T. Mitsui, Y. Watanabe, S. Kobayashi, Y. Haga, M. Esashi ; Sensors and Actuators A, 88, 112 (2000).

23）峯田 貴, 芳賀洋一, 江刺正喜; 電気学会E部門誌, 123,158 (2003).

24) T. Mineta, M. Abe, H. Kubo, E. Makino, T. Shibata ; Proc. of AsiaPacific Conf. on Transducers and Micro-Nano Technol.(APCOT 2004), 3-1, 322 (2004).

25) T. Sugawara, K. Hirota, M. Watanabe, T. Mineta, E. Makino, S. Toh, T. Shibata ; Sensors and Actuators A, 130-131, 461 (2006).

26) T. Mineta, N. Kida, S. Nomura, E. Makino, T. Sugawara, S. Toh, T. Shibata; Sensors and Actuators A, 143-1, 14 (2008).

27) M. Ozaki, N. Kida, T. Mineta, E. Makino, S. Toh, T. Kawashima, T. Shibata ; Tech. Dig. of the 14th Int. Conf. on Solid State Sensors, Actuators and Microsys. (Transuducers'09), 1770 (2009).

28）佐藤 諒, 鎌田隆宏, 峯田 貴; 電気学会論文誌E, 136, 454 (2016).

29) H. Yanatori, T. Mineta, S. Takeuchi, K. Abe ; IEEE-NEMS 2016, 
B1L-A-3 (2016)

30）吉川 弥, 篠部晃生, 菅野公二, 土屋智由, 石田 章, 田畑 修; 電 気学会論文誌E, 128, 151 (2008)

31) S. J. Bolanowski Jr., G. A. Gescheider, R. T. Verrillo, C. M. Checkosky, J. Acount ; Soc. Am., Nov; 84, 1680 (1988).

32) 梁取 大, 阿部 喜, 小野泰弘, 峯田 貴; 第33回センサマイクロ マシンと応用システムシンポジウム, 25am2-LN-209 (2016).

33) 上野敏幸; 精密工学会誌, 79, 305 (2013).

34) Y. Sado, C. Saito, Y. Furuya, Y. Kishi, Z. Yajima, T. Okazaki ; Jpn. J. Appl. Phys., 50, 113001 (2011).

35）斉藤 崇, 浜島美央, 斉藤千尋, 中村元一, 岡崎禎子, 古屋泰文, 室 英夫; 電気学会論文誌E, 132, 183 (2012).

36) J. Ryu, A.V. Carazo, K. Uchino, H. Kim ; Jpn, J. Apply. Phys., 40, 4948 ( 2001).

37) P. Zhao, R. Suchoski, M. Wuttig, I. Takeuchi ; Applied Physics Letters, 94, 243507 (2009)

38）岡田尚樹, 笹㴊貴史, 小池邦博, 峯田 貴; 第33回センサマイクロ マシンと応用システムシンポジウム, 25am2-PS-041, (2016).

39）木村奈津子, 久保田健, 古屋泰文; 日本金属学会誌, 79,441 (2015).
40) T. Kubota, T. Okazaki, Y. Furuya ; J. Mag. Mater, 239 (2002).

41) I. Takeuchi, O. O. Famodu, J. C. Read, M. A. Aronova, K.-S. Chang, C. Craciunescu, S. E. Lofland, M. Wuttig, F. C. Wellstood, L. Knauss, A. Orozco ; Nature Materials, 2, 180 (2003).

42）峯田 貴, 川島健太, 西方孝志, 牧野英司, 三上是右, 岡崎禎子, 古 屋泰文; 表面技術協会第125回講演大会要旨集, 229 (2012).

43）西方孝志, 峯田 貴, 田口涼雅, 川島健太 ; 第5回マイクロナノ工 学シンポジウム, 73 (2013).

44）笹㴊貴史, 岡田尚樹, 佐藤 翼, 小池邦博, 峯田 貴; 電気学会論 文誌E, 136, 408 (2016).

45) O. Ducloux, J. W. Park, N. Tiercelin, P. Pernod, V. Preobrazhensky, M. Hamon, Y. Sakai, H. Fujita ; Solid-State Sensors, Actuators and Microsystems Conference (Transducers'09), 1019 (2009).

46) K. Kawashima, E. Makino, T. Mineta; Trans. Electronics and Communications in Jpn. 98, 30 (2015).

47) T. Mineta, K. Kawashima, R. Taguchi; Microelectronic Eng. 168, 45 (2017).

48) Y. Miura, J. -S. Hong, K. Mishina, T. Shibata, T. Mineta; Asia-Pacific Conf. of Transducers and Micro-Nano Technol. (APCOT 2016), 233 (2016). 